\title{
Comparison between Hypericum triquetrifolium Leaves and Derived Calli in Essential Oil Content
}

\author{
Hoshyar A. Azeez \\ Department of Biology, College of Sciences, Sulamani University, Sulaimaniyah-Iraq. \\ Corresponding Author: hoshyar.azeez@univsul.edu.iq
}

\begin{abstract}
The analysis of essential oil using the in-tube extraction technique (ITEX) from the plant leaves and derived calli (fresh calli, dry calli and cell suspension culture) of Hypericum triquetrifolium Turra., initiated from leaves. The plant grows wild in Kurdistan region of Iraq. Studied parameters were determined using in-tube extraction coupled with gas chromatography - mass spectrometry system (ITEX/ GC-MS). A total of 33 compounds were identified as essential oils in leaves, the dominant constituents were measured such as Hexenal, (E) (12.63\%), Octane, 2,3,3-trimethyl (11.36\%), Pentadecane, 7-methyl- (9.7\%), Undecane (6.15\%) and alpha. -Pinene (5.75\%), while the analysis of fresh calli derived from leaves showed 22 types of essential oil; Dodecane (23.78\%), Nonane, 3-methyl- (10.45\%), Limonene (9.68\%), Furan, 2-pentyl-(9.11\%), Toluene $(8.18 \%)$ and Undecane $(7.45 \%)$. On the other hand, 21 oil components were found in dry calli; the major compounds were identified as Limonene (17.18\%), Undecane (12.21\%), Beta.-Myrcene (5.51\%) and Toluene (4.93\%). However, only 23 oil components were determined in cell suspension culture, the main essential oils were; Undecan (42.92\%), Octane, 2,4,6-trimethyl (13.71\%), Oxirane, 2-(1,1dimethylethyl)-3-methyl (9.84\%), Limonene (6.69\%) and Toluene (2.98\%).
\end{abstract}

[DOI: $10.22401 /$ JNUS.20.2.17]

Keywords: H. triquetrifolium, ITEX, GC-MS, Lemonene, Undecan.

\section{Introduction}

Plants are a main source of new products with medicinal value in drug development. Today, several active compounds derived from different plant parts are important natural drugs and used in worldwide [1]. The genus Hypericum belongs to the Clusiaceae family, encompasses 450 different species, but only sixteen species are found in flora of Iraq [2]. Hypericum triquetrifolium Turra is an herbaceous perennial plant and one of the Iraqi wild species of Hypericaceae which is distributed in the north and north-west of the country, the local Arabic name for this species is Roja and the Kurdish name is Swrnatik [3]. According to the literature, this species contains grate groups of phytochemical like phenolics such as tannic and caffeic acid, flavonoids like rutin and hypersoid [4], hypericin, and psudohypericn [5], and hyperforin [6], essential oil [7] and three new phloroglucinol derivatives named hyperscabrins $\mathrm{A}, \mathrm{B}$, and $\mathrm{C}$, were determined the first time by [8].

The essential oil is defined as the product obtained from different plant organs (roots, stems, leaves, flowers, fruits and seeds) by various methods of distillation such as, hydrodistillation, steam distillation or dry distillation or by other suitable mechanical process. Volatile compounds found only in $10 \%$ of the plant kingdom which are produced and stored in plants in special secretory structures, such as glands, secretory hairs, secretory ducts, secretory cavities or resin ducts [9]. This product is highly complex mixtures of valuable volatile compounds like terpenes, terpenoids and aliphatic derivatives generally characterized by strong odour [10].

Essential oils play very important role inside the plant like defense system and signaling processes, for example, this type of secondary metabolites are participate in plant defense against microorganisms such as bacteria, fungi, different types of plant viruses, insects and herbivorous, attraction of the insects for pollination and fruit dispersing by animals, regulate water relation and allelopathic interactions $[11,12,13]$. Also, they are valuable active compounds intervene as raw material in many industrial fields, like agronomic, food, cosmetics, pharmaceutical, and perfume industries [14]. The production of secondary metabolites from undifferentiated 
plant cells and callus cultures has been studied intensively since the 1960's. Indeed, successful protocols of cell suspension cultures can offer a repeatable method to produce secondary metabolites from elite mother plants with easily controlled conditions and with a continuous supply of material [15].

Previous work was carried out on this species in Iran which revealed a wide range of volatile oil obtained by hydrodistillation from the aerial parts of $H$. triquetrifolium Turra. They were analyzed using GC and GC-MS. Components ( $97.1 \%$ of the total composition) were detected as volatile oils. Germacrene-D (21.7\%), $\beta$-caryophyllene (18.3\%), $\beta$-cadinene $(6.4 \%)$, trans- $\beta$-farnesene $(4.3 \%), \alpha$-humulene (3.8\%), $\beta$-selinene $(3.7 \%), \gamma$-cadinene $(3.3 \%)$ and trans-phytol (3.2\%) were found to be the major constituents [7]. Thus, the aim of the current study was to study the quantitative and qualitative valuable essential oils in plant leaves, fresh, dry calli and cell suspension cultures initiated from leaves.

\section{Materials and Methods \\ Plant collection and identification}

Leaves of $H$. triquetrfolium Turra intact plant were randomly collected from a dry rocky place within the Gllazarda mountain district of Sulaimania province, Iraq (35'21'49.35"N, 45²9'37.31 E; 1100 m.a.s.1.) in September and identified by the taxonomist Dr. Saman A. Ahmad., Filed Crops Dept., Faculty of Agricultural Science, Sulaimani University according to the morphological description presented in flora of Iraq [16]. Plant samples were dried at room temperature $25 \pm 2{ }^{\circ} \mathrm{C}$ for one week to a constant moisture content of $10 \%$. Plant leaves were used as a source of essential oils determination.

\section{Sterilization of explants}

Mature leaves were excised, rinsed with tap water for 10 minutes then submerged in $10 \%$ diluted commercial bleach for 15 minutes, rinsed with sterilization $\mathrm{DH}_{2} \mathrm{O}$, then submerged in $70 \%$ ethanol for 30 seconds. Explants then rinsed with sterilized $\mathrm{DH}_{2} \mathrm{O}$ three times inside a laminar air flow cabinet. The ends of each leaf were cut to remove tissues affected by sterilization solution. Finally, leaf discs $1 \mathrm{~cm}$ in diameter were transferred to the culture medium [16].

\section{Initiation of Callus culture}

Leaf explants were placed on MS medium containing Thidiazuron (TDZ) at the concentration $2.0 \mathrm{mg} / \mathrm{L}$ and indole-3-acetic acid (IAA) at $0.5 \mathrm{mg} / \mathrm{L}$ to determine the most appropriate plant growth regulator for callus induction. The cultures were incubated at $25^{\circ} \mathrm{C}$ for $16 / 8 \mathrm{hrs}$ (light/dark) photoperiod at a light intensity of 1000 lux. The response of these explants to callus initiation was evaluated after 4 weeks of culture [17].

\section{Cell suspension cultures}

Cell suspension cultures were initiated and maintained according to the previously described methods [18 \& 24].

\section{Analysis by ITEX / GC-MS}

The extraction of volatile compounds was performed using the in-tube extraction technique (ITEX). Samples (2, 10 and $20 \mathrm{~g}$ of dry, fresh and cell suspension calli) initiated from leaf explants were incubated respectively at $60^{\circ} \mathrm{C}$ for $20 \mathrm{~min}$. and 30 extraction strokes were performed from the headspace phase of the vial and the volatile compounds were adsorbed onto the ITEX fiber by thermal desorption, an aliquot of the extracted volatiles was directly introduced in the GC injector. The analysis of volatile compounds was carried out using a GC-MS QP-2010 (Shimadzu Scientific Instruments, Kyoto, Japan) model gas chromatograph-mass spectrometer. The volatile compounds were separated on a Zebron ZB-5ms capillary column of $50 \mathrm{~m} \mathrm{x}$ $0.32 \mathrm{~mm}$ i.d and $0.25 \mathrm{~mm}$ film thickness. The carrier gas was helium, $1.3 \mathrm{ml} / \mathrm{min}$ and the split ratio 1:20. The temperature program used for the column oven was: from $40^{\circ} \mathrm{C}$ rising to $2800^{\circ} \mathrm{C}$ at $5^{\circ} \mathrm{C} / \mathrm{min}$ and held for $5 \mathrm{~min}$. The injector, ion-source and interface temperatures were set at $250^{\circ} \mathrm{C}$. The MS mode was electron impact (EI). The mass range scanned was $50-550 \mathrm{~m} / \mathrm{z}$. The volatile compounds were tentatively identified using the spectra of reference compounds from NIST27 and NIST147 mass spectra libraries. The results were expressed as area \% from the total area of peaks $(100 \%)$ [19]. 


\section{Results and Discussion}

The major compounds identified in the essential oils of the plant leaves of $H$. triquetrifolium are listed in Table (1.A) total of 33 types of oils were determined, representing $92.95 \%$ of the total oil recording; Hexenal, (E) (12.63\%), Octane, 2,3,3-trimethyl (11.36\%), Pentadecane, 7-methyl (9.7\%), Naphthalene derivatives $(8.82 \%)$, Undecane $(6.15 \%)$, alpha.-Pinene $(5.75 \%)$, and Cycloheptane, 4methylene-1-methyl-2-(2-1-yl)-1-vinylmethyl-1-propen (4.5\%) are the most predominant of the 33 compounds. In a previous work on $H$. triquetrifolium the essential oils were obtained by hydrodistillation from the aerial parts of plants, they were 1-hexanal $(18.8 \%)$, 3methylnonane $(12.5 \%)$ and - pinene $(12.3 \%)$ were shown to be the major compounds [20], but a total of 109 compounds included $92.2 \%$ of total oils that determined were identified as essential oils were obtained from the aerial parts of Tunisian endemic $H$. triquetrifolium Turra (Clusiaceae) [21]. A total of 22 types of essential oils were identified from fresh calli initiated from leaves, representing $98.26 \%$ of the total oil. The most abundant constituents were Dodecane $(23.78 \%)$, Nonane, 3-methyl(10.45\%), Limonene (9.68\%), Furan, 2-pentyl$(9.11 \%)$, Toluen $(8.18 \%)$, Undecane $(7.45 \%)$, 2,5-Cyclohexadiene-1,4-dione, 2,5-diphenyl (5.7\%) and Eucalyptol (4.07\%) Table (2).

Chemical analysis presented in Table (3) showed that 21 types of essential oils were found in dry calli of $H$. triquetrifolium that initiated from leaf explants grown at $16 \mathrm{hrs}$ light and $8 \mathrm{hrs}$ dark are characterized by a high content of Benzaldehyde derivatives (26.7\%), Limonene (17.18\%), Cyclohexane derivatives (14.67\%), Undecane (12.21\%), Beta.-Myrcene (5.51\%) and Toluene (4.93\%).

Results obtained from this study are in agreement with those of [22], who reported that essential oils isolated from in vitro cultures were less complex than from in vivo plants, while the main essential oil contents in cell suspension culture are; Limonene (6.69\%), Toluene (2.98\%), Eucalyptol $(2.53 \%)$, o-Cymene $(0.77 \%)$ and alpha-Pinene $(0.53 \%)$ as described in Table (4). Results are in accordance with [17, 23], who mentioned that the accumulation of some secondary metabolites in in vitro cultures (callus and cell suspensions) were higher than those in wild type plants after optimization of cultural conditions. This may due to the presence of plant growth regulators (PGRs) supplemented to the medium for callus initiation. The effects of different PGRs on accumulation of some active compounds have previously been studied and confirmed in various plants and their tissue cultures in some medicinal plants that produce secondary metabolites more than intact plant [24]. 
Table (1)

Essential oils Composition in H. triquetrifolium leaves analyzed by Head space.

\begin{tabular}{|c|c|c|c|c|c|}
\hline Essential oil & Ret. time & Conc. $\%$ & Area & Height & SI \\
\hline 1-Penten-3-ol & 4.056 & 2.03 & 680924 & 300847 & 97 \\
\hline Pentane, 2,2,4-trimethyl- & 4.106 & 2.35 & 788545 & 311034 & 97 \\
\hline Furan, 2-ethyl- & 4.245 & 1.03 & 347387 & 176424 & 95 \\
\hline 2-Pentanone, 3-methyl- & 5.104 & 0.37 & 122989 & 58877 & 95 \\
\hline 2-Butenal, 3-methyl- & 5.801 & 0.98 & 327951 & 124524 & 95 \\
\hline Cyclohexane, (1,1-dimethylethyl)- & 6.061 & 3.29 & 11105612 & 392010 & 99 \\
\hline 2-Hexenal, $(\mathrm{E})-$ & 7.37 & 12.63 & 4238895 & 1630041 & 99 \\
\hline Octane, 2,3,3-trimethyl- & 7.671 & 11.36 & 3814119 & 1652218 & 99 \\
\hline p-Xylene & 7.848 & 1.08 & 363192 & 164253 & 94 \\
\hline Hexane, 2,2,3,3-tetramethyl- & 8.661 & 6.42 & 2156533 & 848513 & 99 \\
\hline .alpha.-Pinene & 9.737 & 5.75 & 1929745 & 596385 & 99 \\
\hline Nonane, 3-methyl- & 10.833 & 0.41 & 138437 & 68805 & 99 \\
\hline Octane, 3,5-dimethyl- & 11.763 & 0.48 & 161330 & 94975 & 81 \\
\hline Benzene, 1-ethyl-2,4-dimethyl- & 12.61 & 1.04 & 349893 & 126768 & 93 \\
\hline $\begin{array}{l}\text { Cyclohexanol,1-methyl-4-(1-methylethenyl)-, } \\
\text { acetate }\end{array}$ & 12.766 & 3.01 & 1011443 & 388712 & 96 \\
\hline Benzeneacetaldehyde & 13.223 & 1.08 & 361428 & 127717 & 98 \\
\hline Pentadecane, 7-methyl- & 13.837 & 9.79 & 3284678 & 1371280 & 99 \\
\hline $\begin{array}{l}\text { 2-Furanmethanol,5-ethenyltetrahydro- } \\
\text { alpha.,.alpha.,5-trimethyl- }\end{array}$ & 14.098 & 0.82 & 275328 & 102378 & 87 \\
\hline Undecane & 14.995 & 6.15 & 2063901 & 816827 & 98 \\
\hline Nonanal & 15.141 & 0.85 & 286722 & 103367 & 96 \\
\hline Undecane, 2,3-dimethyl- & 17.237 & 0.52 & 175015 & 70977 & 96 \\
\hline Hexadecane & 18.168 & 1.15 & 386947 & 145230 & 96 \\
\hline Undecane, 3-methyl- & 20.114 & 0.02 & 8132 & 15463 & 68 \\
\hline Dodecane & 21.205 & 0.29 & 97392 & 54539 & 81 \\
\hline Ylangene & 23.401 & 0.84 & 280950 & 89826 & 96 \\
\hline $\begin{array}{c}\text { Copaene } \\
\end{array}$ & 23.585 & 1.94 & 652656 & 225799 & 91 \\
\hline $\begin{array}{l}\text { Cycloheptane,4-methylene-1-methyl-2-(2- } \\
\text { methyl-1-propen-1-yl)-1-vinyl- }\end{array}$ & 24.853 & 4.5 & 1509083 & 427415 & 98 \\
\hline $\begin{array}{l}\text { 1R,3Z,9S-2,6,10,10 Tetramethylbicyclo } \\
\text { [7.2.0]undeca-2,6-diene }\end{array}$ & 25.093 & 0.9 & 303667 & 104592 & 99 \\
\hline $\begin{array}{c}\text { Naphthalene,1,2,3,4,4a,5,6,8aoctahydro-7- } \\
\text { methyl-4-methylene-1-(1-methylethyl)-, } \\
\text { (1.alpha.,4a.alpha.,8a.alpha.)- }\end{array}$ & 26.294 & 3.85 & 1292126 & 465111 & 98 \\
\hline $\begin{array}{c}\text { Naphthalene,1,2,3,4,4a,5,6,8aoctahydro-7- } \\
\text { methyl-4-methylene-1-(1-methylethyl)-, } \\
\text { (1.alpha.,4a.alpha.,8a.alpha.)- }\end{array}$ & 27.325 & 1.92 & 643098 & 213535 & 98 \\
\hline $\begin{array}{c}\text { Naphthalene1,2,3,5,6,8a-hexahydro-4,7- } \\
\text { dimethyl-1-(1-methylethyl)-, (1S-cis)- }\end{array}$ & 27.423 & 1.62 & 544998 & 182986 & 89 \\
\hline $\begin{array}{l}\text { Naphthalene,1,2,3,4-tetrahydro-1,6 dimethyl- } \\
\text { 4-(1-methylethyl)-, (1S-cis)- }\end{array}$ & 27.524 & 1.43 & 478556 & 163600 & 96 \\
\hline 2,5-Cyclohexadiene-1,4-dione,2,5 diphenyl- & 45.681 & 3.05 & 1022131 & 265322 & 96 \\
\hline
\end{tabular}

Ret. time $=$ Retention time $S I=$ Similarity 
Table (2)

Composition of essential oils in $\mathrm{H}$. triquetrifolium fresh calli initiated from leaves analyzed by Head space.

\begin{tabular}{|c|c|c|c|c|c|}
\hline Essential oil & Ret. time & Conc. $\%$ & Area & Height & SI \\
\hline Oxirane, 2-(1,1-dimethylethyl)-3-methyl- & 4.666 & 2.53 & 294818 & 123374 & 94 \\
\hline 1,3,5-Cycloheptatriene & 5.176 & 0.74 & 86664 & 54290 & 96 \\
\hline Toluene & 5.273 & 8.18 & 954154 & 393178 & 98 \\
\hline Furan, 2,3-dihydro-4-methyl- & 5.694 & 1.0 & 116384 & 50295 & 98 \\
\hline Cyclohexane, (1,1-dimethylethyl)- & 5.963 & 1.93 & 225213 & 80843 & 98 \\
\hline Octane, 2,3,3-trimethyl- & 7.61 & 1.61 & 188116 & 91343 & 94 \\
\hline $\begin{array}{c}\text { Undecane } \\
\end{array}$ & 8.617 & 7.45 & 868926 & 290971 & 99 \\
\hline .alpha.-Pinene & 9.701 & 1.07 & 125175 & 56556 & 98 \\
\hline Benzaldehyde & 10.613 & 2.39 & 278944 & 92302 & 95 \\
\hline Nonane, 3-methyl- & 10.815 & 10.45 & 1219198 & 418573 & 99 \\
\hline Phenol & 10.964 & 1.35 & 157034 & 64554 & 96 \\
\hline Furan, 2-pentyl- & 11.43 & 9.11 & 1062462 & 316604 & 99 \\
\hline o-Cymene & 12.603 & 0.68 & 79048 & 35575 & 99 \\
\hline Limonene & 12.761 & 9.68 & 11129006 & 401965 & 99 \\
\hline Eucalyptol & 12.886 & 4.07 & 4775269 & 168715 & 98 \\
\hline Benzeneacetaldehyde & 13.228 & 1.09 & 127549 & 47386 & 100 \\
\hline "Heptane, 5-ethyl-2-methyl- & 13.847 & 1.05 & 121992 & 53788 & 99 \\
\hline $\begin{array}{c}\text { Acetophenone } \\
\end{array}$ & 13.949 & 3.05 & 355683 & 121064 & 99 \\
\hline Dodecane & 15.006 & 23.78 & 2773916 & 1094373 & 99 \\
\hline 2-Nonenal, (E) & 16.939 & 0.53 & 62415 & 30908 & 94 \\
\hline Propanoic acid, 2-methyl-, decyl ester & 33.797 & 0.82 & 95712 & 39494 & 99 \\
\hline $\begin{array}{c}2,5-C y c l o h e x a d i e n e-1,4-d i o n e, 2,5- \\
\text { diphenyl- }\end{array}$ & 45.716 & 5.7 & 665291 & 193871 & 98 \\
\hline
\end{tabular}

\section{Ret. time $=$ Retention time SI= Similarity}

In case of $H$. perforatum L. one hundred and thirty four compounds were identified mounting; $98.7 \%$ of the total oil, were obtained from fresh aerial parts. The main components of the oil were: germacrene D (18.6\%), 2-methyloctane (9.5\%), bicyclogermacrene $(5.0 \%)$ and $(E)$ - $\beta$-ocimene $(4.6 \%)$ [25], some of these oil derivatives were not found in the current study, this may due to the variation of Hypeicum sp. Mainly because seasonal variation, geographic distribution, phenological cycle and type of the organ in which essential oils are produced and/or accumulated [26, 27], as well as conditions of biomass growth (e.g. in vitro or in vivo) [26]. These factors are known to influence the essential oil content and composition of this genus.

In the present study, the monoterpene hydrocarbon (limonene and cymene) recorded high percentage in dry callus cultures $(17.18 \%$ and $2.48 \%$ ) respectively, while suspension culture initiated from leaves recorded low limonene content (6.69\%) but cymene concentration in fresh calli recorded minimum percentage $(0.68 \%)$. On the other hand, these compounds were not detected in plant leaves. Fresh and dry calli initiated from leaves accumulated $4.07 \%$ and $1.79 \%$ of eucalyptol respectively while cell suspension cultures accumulated $2.53 \%$. Dodecane showed the highest percentage $(23.78 \%)$ in fresh callus culture, while dodecane recorded low amount in plant leaves reached $0.29 \%$, but dodecane was not detected in dry calli and cell suspension cultures that initiated from leaf explants grown at $16 \mathrm{hrs}$ photoperiod. 
Table (3)

Essential oils composition of $\mathrm{H}$. triquetrifolium dry calli initiated from leaves analyzed by Head space.

\begin{tabular}{|c|c|c|c|c|c|}
\hline Essential oil & Ret. time & Conc. $\%$ & Area & Height & SI \\
\hline Toluene & 5.433 & 4.93 & 417521 & 166554 & 95 \\
\hline 3-Penten-2-ol & 5.61 & 1.76 & 149272 & 47052 & 91 \\
\hline $\begin{array}{l}\text { Cyclobutanol, 2-ethyl- } \\
\text { 2Ethylcyclobutanol }\end{array}$ & 6.003 & 2.08 & 176277 & 38812 & 90 \\
\hline $\begin{array}{c}\text { Cyclohexane, }(1,1 \text { dimethylethyl } \\
\text { Cyclohexane, tert-butyl tert } \\
\text { Butylcyclohexane 1-tert- } \\
\text { Butylcyclohexane } \\
\end{array}$ & 6.088 & 14.67 & 1243806 & 530639 & 99 \\
\hline Acetic acid, butyl ester & 6.406 & 0.93 & 78623 & 29848 & 99 \\
\hline Acetic acid, pentyl ester & 8.083 & 0.73 & 61944 & 31363 & 97 \\
\hline Hexane, 2,4-dimethyl- & 8.703 & 0.65 & 54782 & 32771 & 94 \\
\hline $\begin{array}{l}\text { 2,4-Heptadiene, 2,4-dimethyl- (4E)- } \\
\text { 2,4-Dimethyl-2,4-heptadiene }\end{array}$ & 9.054 & 2.39 & 202174 & 88894 & 99 \\
\hline alpha.-Pinene & 9.783 & 1.79 & 151762 & 65873 & 100 \\
\hline Butane, 2,2-dimethyl- & 10.875 & 0.62 & 52876 & 22688 & 100 \\
\hline .beta.-Myrcene & 11.47 & 5.51 & 467126 & 143408 & 99 \\
\hline Acetic acid, hexyl ester & 12.167 & 0.68 & 57662 & 29725 & 95 \\
\hline Octane, 3,3-dimethyl- & 12.167 & 0.48 & 40632 & 23788 & 39 \\
\hline o-Cymene & 12.647 & 2.48 & 210525 & 86904 & 99 \\
\hline Limonene & 12.81 & 17.18 & 14556494 & 561348 & 99 \\
\hline $\begin{array}{c}\text { Eucalyptol } \\
\end{array}$ & 12.936 & 1.79 & 152019 & 61452 & 94 \\
\hline $\begin{array}{c}\text { 3-Ethyl-3-methylheptane } \\
\text { Heptane, 3-ethyl-3-methyl- }\end{array}$ & 13.564 & 0.35 & 29953 & 21762 & 90 \\
\hline Undecane & 15.042 & 12.21 & 1035042 & 423956 & 98 \\
\hline $\begin{array}{c}\text { Benzaldehyde, 2,4-dimethyl- } \\
\text { 2,4-Dimethylbenzaldehyde } \\
\text { 2,4-Dimethylbenzenecarboxaldehyde } \\
\end{array}$ & 18.804 & 26.7 & 2263483 & 755977 & 99 \\
\hline Benzene, 1,3-bis(1,1-dimethylethyl) & 19.74 & 0.77 & 65192 & 26861 & 90 \\
\hline Hexane, 3,3-dimethyl & 20.5 & 0.54 & 45408 & 16352 & 85 \\
\hline
\end{tabular}

\section{Ret. time $=$ Retention time $S I=$ Similarity}

High percentage of $\alpha$-pinene $(5.57 \%)$ was found in plant leaves while the less percentage was found in cell suspension cultures $(0.53 \%)$. Undecane was found at high levels $(42.92 \%)$ in cell suspension cultures initiated from leaf explants. Meantime percentage in plant leaves was found to be lower than cell suspension cultures (6.15\%). Data also exhibit a high amount of toluene in leaves fresh calli $(8.18 \%)$ compared with the dry calli and cell suspension cultures recording $4.93 \%$ and $2.98 \%$ respectively, while this was not detected in intact leaves.
To our knowledge, the analysis of essential oil in the present study using ITEX/ GC-MS method was reported for the first time in callus and cell suspension cultures. 
Table (4)

Essential oil composition in $\boldsymbol{H}$. triquetrifolium cell suspension cultures initiated from leaves analyzed by Head space.

\begin{tabular}{|c||c|c|c||c|c|}
\hline Essential oil & Ret. time & Conc. \% & Area & Height & SI \\
\hline \hline Oxirane, 2-(1,1-dimethylethyl)-3 methyl & 4.763 & 9.84 & 2656847 & 838369 & 99 \\
\hline \hline Toluene & 5.375 & 2.98 & 805194 & 355684 & 99 \\
\hline \hline 2-Buten-1-ol, 3-methyl & 5.533 & 2.21 & 595911 & 197306 & 99 \\
\hline 2-Butenal, 3-methyl & 5.739 & 2.87 & 775125 & 257735 & 99 \\
\hline 3-Hexen-1-ol, (Z)- & 7.456 & 0.38 & 102941 & 49632 & 95 \\
\hline 1-Hexanol & 7.804 & 0.37 & 100174 & 49340 & 100 \\
\hline \hline 1-Butanol, 3-methyl-, formate & 8.035 & 1.83 & 494530 & 216136 & 98 \\
\hline Octane, 2,4,6-trimethyl- & 8.664 & 13.71 & 3702148 & 1071360 & 99 \\
\hline 2,4-Heptadiene, 2,4-dimethyl- & 9.024 & 0.36 & 96929 & 41363 & 99 \\
\hline alpha.-Pinene & 9.75 & 0.53 & 144451 & 65282 & 99 \\
\hline Benzaldehyde & 10.644 & 0.8 & 215772 & 93393 & 96 \\
\hline \hline Nonane, 3-methyl & 10.846 & 2.38 & 644051 & 256334 & 99 \\
\hline \hline Beta.-Myrcene & 11.434 & 2.12 & 573587 & 229170 & 98 \\
\hline o-Cymene & 12.629 & 0.77 & 207930 & 73352 & 94 \\
\hline \hline Limonene & 12.789 & 6.69 & 1807152 & 607698 & 98 \\
\hline Eucalyptol & 12.906 & 2.53 & 682224 & 220450 & 98 \\
\hline \hline Octane, 2,3,3-trimethyl- & 13.861 & 0.44 & 119166 & 64685 & 98 \\
\hline Acetophenone & 13.982 & 1.52 & 410591 & 129993 & 98 \\
\hline Undecane & 15.018 & 42.92 & 11589833 & 4587385 & 99 \\
\hline \hline Anisole, p-allyl- & 18.199 & 1.68 & 452690 & 166713 & 98 \\
\hline n-Dodecyl acetate & 29.538 & 0.85 & 228509 & 87757 & 97 \\
\hline Butyric acid, tetradecyl ester & 33.806 & 1.7 & 460364 & 154026 & 100 \\
\hline 2,-Cyclohexadiene-1,4-dione, 2,5 \\
diphenyl- & 45.727 & 0.52 & 139639 & 65818 & 80 \\
\hline \hline
\end{tabular}

\section{Ret. time $=$ Retention time SI $=$ Similarity}

\section{Conclusion}

The comparative analysis of the essential oil of $H$. triquetrifolium obtained by ITEX technique showed variations in quantitative and qualitative oil content. Essential oil composition in in vitro cultures (callus and cell suspension) produce more compounds than intact plant. The essential oil extracted from plant leaves were more complex than that extracted from in vitro culture.

\section{Acknowledgment}

I wish to express my sincere gratitude to Dr. Sonia Socaci from Food Science and Technology Dept., USAMV-Cluj for the GCMS analysis.

\section{References}

[1] Veeresham, C. Natural products derived from plants as a source of drugs. J Adv Pharm Technol Res. 3(4): 200-201, 2012.
[2] Robeson, N.K.B. Studies in the genus Hypericum L. (Clusiaceae) 1. Section 9. Hypericum sensu lato (part 3): subsection 1. Hypericum series 2. Senanensia, subsection 2. Erecta and section 9b. Graveolentia Syst. Bio divers, 4: 19-98, 2006.

[3] Al-Rawi, A.; Chakravarty, H.L. Medicinal Plants of Iraq. $2^{\text {nd }}$ edition. Ministry of Agriculture and Irrigation. Iraq, Baghdad, 54: 67-78, 1988.

[4] Cirak, C.; Radusiene, J.; Ivanauskas, L.; Jakstas, V.; Camasi, N. Phenological changes in the chemical content of wild and greenhouse-grown Hypericum pruinatum: flavonoids. Turk J Aric For 38: 362-370, 2014.

[5] Azeez, H.A.; Ibrahim K. M. Hypericum triquetrifolium Callus Cultures a Potential Source of Phenolics and Flavonoids. JZS Part A, Special Issue, Vol. 16, 2014. 
[6] Tawahaa, K.; Mohammad, G.; Tamam ElElimat, C.; Feras, Q. A.; lali, d. Determination of hypericin and hyperforin content in selected Jordanian Hypericum species. Ind. Crops Prod. Vol, 32, Issue 3, 241-245, 2010.

[7] Sajjadi, S.E.; I. Mehregan, I.; Taheri, M. Essential oil composition of Hypericum triquetrifolium Turra growing wild in Iran. Research in Pharmaceutical Sciences, 10(1): 90-94, 2015.

[8] Ma, J.; Ji, TF.; Yang, JB.; Wang, AG.; Su, YL. Three new phloroglucinol derivatives from Hypericum scabrum. J Asian Nat Prod Res. 14(5):508-14, 2012.

[9] Liolios, C.C.; Graikou, K.; Skaltsa, E. \& Chinou, I. Dittany of Crete: A botanical and ethnopharmacological. Journal of Ethnopharmacology, Vol.131, 229-241, 2010.

[10] Bertoli, A.; Menichini.; Mazzetti, M.; Spinelli, G.; Morelli, I. Volatile constituents of the leaves and flowers of Hypericum triquetrifolium Turra. Flavour fragr. J. 18, 91-94, 2003.

[11] Burt, S. Essential oils: their antibacterial properties and potential applications in foods- A review. Int. J. Food Microbiol. 94(3): 223-253, 2004.

[12] Taiz, L.; Zeiger, E. Plant Physiology, $5^{\text {th }}$. Sinauer Associates. Sunderland, MA, 2010.

[13] Bakkali, F.; Averbeck, S.; Averbeck, D.; Idaomar, M. Biological effects of essential oils. Food and Chemical Toxicology, Vol. 46, 446-475, 2008.

[14] Zygadlo, J.A.; Juliani, HR Jr. Bioactivity of essential oil components. Curr Top Phytochem 3:203-214, 2000.

[15] Tisserat, B.; Vaughn, S.; Silman, R. Influence of Various Tissue Culture Technologies on Essential Oil Metabolism. Plant Bioactives in Traditional Medicine. D. Majumdar, J. Govil, V. Singh and R. Sharma. Houston, Studium Press, LLC. 9: 321-334, 2005.

[16] Caruso, J.; Callahan, J.; DeChant, C.; Jayasimhulu.; Winget, G. Carnosic acid in green callus and regenerated shoots of Rosmarinus officinalis. Plan. Cell Reports., (19): 500-503, 2000.

[17] Azeez, H. A. Induction of some secondary metabolites in Hypericum triquetrifolium
Turra., using some biotechnological approaches in vitro. PhD Dissertation, Bilogy Dept. College of Science, Sulaimani Univ. Iraq, 2012.

[18] Salanta, L.C.; Tofana, A. M.; Socaci, S.A.; POP, C.; Michiu, D.; Ichiu, D.; Farcas, A.Determination of the Volatile Compounds from Hop and Hop Products using ITEX/GC-MS Technique. Journal of Agroalimentary Processes and Technologies, 18(2), 110-115, 2012.

[19] Yuce, E.; Bagci, E. The essential oils of the aerial parts of two Hypericum taxa (Hypericum triquetrifolium and Hypericum aviculariifolium subsp. depilatum var. depilatum (Clusiaceae)) from Turkey. Natural Product Research, 1-6, 2011.

[20] Hosni Karim, H.; Mssada, K.; Ben, T.; Mouna, CT.; Marzouk, B. Essential oil composition of Hypericum triquetrifolium Turra. aerial Parts. The Italian Journal of Biochemistry Vol. 56 (1), 2007.

[21] Ana, P.; Guedes, M. F. Essential oils from plants and in vitro shoot cultures of Hypericum androsaemum L., H. perforatum L. and $H$. undulatum Schousboe ex. Wild. College of Science, Biology Dept. Minho Univ., 2009.

[22] Rojbayani, S.A.K. Induction and stimulation of some phytochemicals from Hypericum perforatum L. in vitro. $\mathrm{PhD}$. Dissertation. Al- Mustansiriya Univ. 59-67, 2007.

[23] Azeez, H. A.; Ibrahim, K. M. Effect of Biotic Elicitors on Secondary Metabolite Production in Cell Suspensions of Hypericum triquetrifolium Turra. Bulletin UASVM Horticulture. 70 (1), 26-33, 2013.

[24] Aleksandra, S. D. Chemical composition of Hypericum perforatum L. essential oil. Advanced technologies. 4(1), 64-68, 2015.

[25] Guedes, A.P.; Amorim, L. R.; Vicente, A.M.S.; Ramos, G.; Fernandes-Ferreira, M. Essential Oils from Plants and in Vitro Shoots of Hypericum androsaemum L. J. Agric. Food Chem. 51(5),1399-1404, 2003.

[26] Guedes, A. P.; Amorim, L. R.; Vicente, A. M. S.; Ramos, G.; Fernandes-Ferreira, M. Variation of the essential oil content and composition in leaves from cultivated plants of Hypericum androsaemum L Phytochemical Analysis. 15,146-151, 2004. 